Article

\title{
Integrating Digital Twin Technology Into Large Panel System Estates Retrofit Projects
}

\author{
Paulina Duch-Zebrowska * and Katarzyna Zielonko-Jung \\ Department of Environmental Design, Faculty of Architecture, Gdańsk University of Technology, Poland; \\ E-Mails: paulina.zebrowska@pg.edu.pl (P.D.-Z.), katarzyna.zielonko-jung@pg.edu.pl (K.Z.-J.) \\ * Corresponding author
}

Submitted: 30 April 2021 | Accepted: 24 July 2021 | Published: 17 November 2021

\begin{abstract}
As sustainability is now a standard for the proposed developments, the focus ought to be shifted towards the existing buildings and, among them, the worldwide stock of large panel system (LPS) buildings. Major upgrades and retrofits were done to some of the LPS estates in Germany and France, but a leading sustainable way must still be developed for LPS buildings in Eastern European countries, where apartments in those half-a-century-old estates are privately owned. Both sustainability and ownership issues make the demolition option redundant, and therefore the method for deep thermal retrofit and urban intervention is being developed with the use of BIM simulation tools. Digital twin (DT) technology allows for calibration to intertwine with the Internet of Things applications that reward the inhabitants for sustainable behaviour while feeding the relevant data back to the DT. Thanks to this, smart technology can be used to raise the level of social participation in the projects and thus help educate the end-users, which is paramount in establishing and maintaining good ecological habits, and as such, also for the efficacy and viability of the final endeavour. This article proposes a procedure of creating a 3D model typology repository for facilitating DT technology to provide a good analytical tool for community consultation and enable virtual testing of technical and urban solutions before implementation. It aims to determine the method for virtual technology to give deteriorating estates a new lease of life and improve their perception in the wider community while being a conduit for the adaptation of CEE to the digital revolution.
\end{abstract}

\section{Keywords}

3D model repository; BIM simulation tools; digital twin technology; end-user education; large panel system; modular design; participation projects; smart technology; sustainable refurbishment; thermal upgrade

\section{Issue}

This article is part of the issue "Towards Digital Urban Regeneration: Embedding Digital Technologies Into Urban Renewal Processes and Development" edited by Dalit Shach-Pinsly (Technion-Israel Institute of Technology, Israel).

(C) 2021 by the authors; licensee Cogitatio (Lisbon, Portugal). This article is licensed under a Creative Commons Attribution 4.0 International License (CC BY).

\section{Introduction}

This article is the first output of a project that aims to find a new lease on life for the existing modular estates built widely across post-WWII Europe. This article assesses the possibility of using modern design techniques in thermal retrofit projects for such buildings to inform and advise policymakers, and provide a clear path forward to reduce the buildings' operational carbon footprint.

The technology that prevails in modern design is building information modelling (BIM), which has gained recognition in the construction industry since its implementation as it enables early clash detection and therefore reduces the construction cost. The next step taken by the construction industry was the integration of the buildings' predicted and actual performance, which has been achieved by building performance simulation (BPS) tools (Hopfe et al., 2017) widely used in the preparation of building management systems (BMS). Nowadays, the use of BIM and BPS does not stop with the completion of the construction works-the BMS and the Internet of Things provide a steady data flow to the simulation 
software, creating a constantly growing virtual twin of the actual building. This article provides an overview of the possibilities of using the above methods in the retrofit projects of existing buildings, particularly in large panel system (LPS) buildings.

As described in the Statistical Review of World Energy by BP (2020), primary energy consumption continues to grow every year and, as such, each action in this regard requires a substantial reduction in energy consumption. Since buildings are responsible for $36 \%$ of $\mathrm{CO}_{2}$ emissions in the EU, as shown by Lorenzo-Sáez et al. (2020), reducing their energy consumption should be a priority. LPS buildings constitute a high percentage of all residential buildings in Eastern Europe. Due to comparable technologies, one solution may affect a significant number of buildings by similar initiatives; therefore, finding an answer for the most cost-effective thermal retrofit of LPS buildings may significantly reduce $\mathrm{CO}_{2}$ emissions considering the scale effect. Based on this, as well as on the climate change and our response to it being our collective responsibility, LPS buildings were chosen for the research.

The first part of this article describes the LPS and identifies its general strengths and weaknesses. The second part explores the software that may be used to create new opportunities for LPS estates. This is followed by section 3 , which considers the impact new technologies have on end-user education and the way it affects estate sustainability. The conclusion summarizes the results of the analysis and provides a roadmap for the next steps of the project.

\section{Main Considerations of the Research}

\subsection{Principles of the Large Panel System}

LPS is a construction system used since the late 1950s that allowed for swift assembly of the building from prefabricated modules. Due to the centralized design and management of the construction process at the government level, a closed typology of solutions was utilized. However, the possibility to provide big quantities of habitable units in a short time through the erection of prefabricated LPS buildings was part of the proposed solution to the main hindrance of the quick-paced progression of the second Industrial Revolution post-WWII, which was the insufficient workforce influx due to the lack of housing for labour workers willing to migrate into cities in search of a better life (Korzeniewski, 1981, p. 9). This approach, described also by Dekker and Van Kempen (2005), was widely adopted in many countries, with more than 50 million LPS type apartments created in 1956-1991 (Eurostat, 2018); such solutions remained popular until as late as the 1980s, primarily in countries under the influence of the former USSR, where the central government established the housing market strategy and policy. While some LPS buildings were erected in Western Europe as well, the free-market laws of the Western economies allowed for the diversity of the systems adopted, and the idea of a typical LPS was swiftly abandoned due to the lack of design diversity. Currently, prefabricated concrete elements are still widely used in the construction industry however, since they do not fulfil the typology criteria, they are not covered by this research article.

The LPS systems varied between countries and received local names, which demonstrates the local societies' connection to them: Germany-Planttenbau, Russia-Panelnye-doma, Poland-Wielka plyta, RomaniaBloc or Systematization, Czechia and Slovakia-Panelák or Sidlisko, and Hungary-Panelház.

LPS buildings have become a familiar part of the urban landscape. Due to the common denominator-the closed typology of solutions in prefabricated reinforced concrete elements, enabling effective building construction by using modules - the local varieties were omitted in this article and are all referred to as "LPS" for ease of comprehension.

\subsection{Strengths and Weaknesses}

LPS estates were typically built-in rural areas adjacent to the existing towns. It was an extensive urban design undertaking - the new areas of the city developed on pristine sites. Up until that time, Europe's urban system development was predominantly a slow-paced and long-term endeavour (Bosker et al., 2008). It was the first time in history with so many extensive developments happening at once. The urban planners were experimenting with various designs in terms of road layout, as well as locations of service outlets and amenities, all of which were designed from scratch. Since then, LPS estates have become part of the city with broad transport and connections, but the original urban design remained part of the estates. The centralized policy at the early stages of the rapidly increasing urbanization of East European cities post-WWII enforced the universal use of the urban design standard. The standard, as described by Korzeniewski (1981, pp. 64-67), consisted in setting up basic amenities like estate-level services and a primary school within walking distance-no more than 800 meters away from the furthest residential building entrance. Incidentally, this approach has now resurged due to the publication of Jeff Speck's book Walkable City Rules (2018).

The main idea of LPS estates was based on the uniform needs of the citizen, as described by the centralized standard, which resulted in the lack of individualism and poor aesthetics - a weak point indicated by residents in all media and internet relations (see, for example, "Wady i zalety bloków z wielkiej płyty," 2020), and also described by Gribat and Huxley (2015, Chapter 8, p. 165). However, the national design standard provided an outline of the space required to fulfil the social and active recreation needs of the community members as understood by policymakers. As the land was obtained by expropriation of farmers for the greater 
good of society, the estates were designed lavishly, with free space between the buildings often exceeding 60 meters.

As further described by Korzeniewski (1981, pp. 61-63), the central urban guidelines included the requirements for natural air corridors, sunlight, and overshadowing, as well as the distance between buildings. This is because such estates were intended for people moving in from rural areas, who were used to having fences to guard them against their neighbours' prying eyes. The spaces between the buildings allowed for greenery, private and public garden areas adjacent to the buildings, wide pavements, and playgrounds surrounded by trees that provided shade for playing children while also being far enough from the buildings not to cause any issues due to root overgrowth or overshadowing of apartment windows. LPS estates feature various green areas suitable for various uses, ranging from neighbourhood fairs, through outdoor sports, to enabling everyday activities for the elderly and young children. Modern residential developments use the space available more sparingly as they need to increase the revenue gained from the site. The distances between buildings and the green areas on the estates are two of the most often raised advantages of LPS estates over their 21st century counterparts, as described in many online articles providing information for potential buyers in Poland, like the law firm Pewny Lokal (2020). Nonetheless, at the time the LPS estates were built, vehicle use was not as prevalent as it is nowadays. Therefore, the lack of sufficient parking spaces is the primary disadvantage always indicated by LPS estate inhabitants, as is the deteriorating condition of open spaces - an opinion often shared on social media and online message boards for inhabitants, among many others, on the online forum of Gazeta.pl (2018).

The LPS estates were erected on the pristine sites that had been used as agricultural land only a few years before, and as such, had no proper roads or amenities; however, these quickly followed once the estates became populated. Nowadays, the proximity to local amenities was shown to be advantageous for inhabitants in several studies, although the deterioration of local services under pressure from bigger shopping centres was also described as a growing tendency, with only $37 \%$ of respondents to public opinion polls using local shops to satisfy most of their shopping needs (Frendler-Bielicka, 2013).

Low workmanship standards are another issue commonly raised in the debate on LPS buildings' future, as described in energy analyses (Ostańska, 2009). The connections between the panels allowed for higher levels of infiltration and raised concerns regarding the safety of welded connections due to their exposure to elements (Tofiluk, 2017). Therefore, each project shall be preceded by a structural assessment, as per industry standards. However, airtightness tests performed as part of past thermal retrofit projects have shown a nearly $20 \%$ improvement, as evidenced by Dębowski et al. (2014), with such projects reducing the exposure of welded connections and further deterioration.

The next factor to consider during works on LPS buildings is the issue of ownership. In Germany, where most radical refurbishments have been performed, including Märkisches Viertel in Berlin by Gesobau (Lössl, 2016), which became the world's largest low carbon fully accessible estate, many LPS buildings have been abandoned and the apartments are mainly tenured, making any refurbishment works easier. Following the system transformation of the early 1990s, the inhabitants of LPS buildings in most Eastern European countries had the opportunity to acquire apartments at a fraction of their value. The move was welcomed by the residents but at the same time shrewd by the governments due to the transfer of responsibility for the technical state of the buildings that were becoming increasingly deteriorated every year. The buildings' technical decline was accompanied by a decline in the condition of the internal services, like pipework and electricity, which impacts the general efficiency of building systems.

As mentioned above, the lack of individualism caused by the design typology lowers the attractiveness of LPS estates to the public. However, the examples of thermal modernization projects that brought the LPS buildings to a higher aesthetic standard, like Märkischen Viertel or Grand Parc Bordeaux (Miesarch, 2019), are inducing new ways of thinking for all other estates.

\subsection{Main Considerations}

Originally, the average design life for LPS buildings was supposed to be 50-60 years, with the shortest design life of 25 years envisaged for the Russian Khrushchyovka designed to resolve a temporary housing shortage (Absimetov \& Solovev, 2020). Once that time elapsed, there were numerous suggestions, mainly in France, Germany, and the UK, to demolish LPS buildings and make space for new developments. While it might have been a tempting option, as estates originally built on pristine sites with no infrastructure are nowadays located in urbanized areas and benefit from such local amenities as schools, shops, and public transport networks, considering the growing problem of sand shortage on the world construction market, as described by Beiser (2018), as well as the amount of embodied carbon in the concrete panels (Anderson \& Moncaster, 2020), demolition cannot be deemed a sustainable option for site recovery. Additionally, technical and structural analyses have been performed in many countries, e.g., in Poland in 2019 (Instytut Techniki Budowlanej, 2019), which established that the buildings are structurally sound. With the embodied carbon remaining constant, the main consideration of this research project is how to reduce the impact on the environment during the use of buildings and make the estates more attractive for occupiers. 


\section{Digital Twin Technology Use in Large Panel System Retrofit Projects}

The analysis of the geometry and correlation between systems of the designed building before the commencement of construction work is the main benefit of using the BIM system, as it allows for early intervention in case any discrepancies occur. As such, the BIM tool helps the design team to increase productivity, plan the expenditure, and manage the acceptable risk of development by bringing a high level of information to the decision-making process. This is the reason for BIM becoming entrenched in the new development design, as commercial practices and developers are constantly increasing revenue while reducing investment project risk. For any successful project, five key aspects of the strategic approach are needed before implementation: assessment, plan, finance, decision, and risk management (Ruggeri et al., 2020). Effectively used BIM tools help with three initial ones-assessment, plan, and finance-while also providing data for decision making and, due to the level of information collected, help with risk management. Meanwhile, BPS tools provide a quick analysis of the estimated energy consumption and how it gets affected by changes and tweaks in the planned projects. Similar to new development projects, the above key aspects determine the success of refurbishment projects as well. Due to the multi-layered challenges facing LPS refurbishment, ranging from electrical wiring to urban planning, the use of BIM and BPS tools in retrofit projects helps plan works with the largest energy efficiency at the lowest expenditure achievable.

The most time-consuming element of work is the creation of library of materials and products that match the original LPS buildings as the standard software library of BIM materials does not match the physical attributes of 50-year-old concrete. The external walls, slabs, windows, doors, and roof build-up all need to be re-created in the software to allow for flexibility in the model's energy performance settings. The thermal properties of the elements are subsequently imported to the simulation engine via the energy model.

The two types of software initially analysed are Revit with the simulation tool Insight, as well as IES VE with IES ISCAN; they were initially chosen from a list of software most commonly used in the architectural education system prepared by Hopfe et al. (2017). The authors' consideration in choosing the software for initial analysis was to consider the systems that are widely used to ensure the efficacy of the unabridged project. They both work at a different level of information-Revit, which is mainly a tool for the construction industry, requires a higher level of detail, making it more time-consuming. However, due to the wide use of typology in the construction of LPS buildings, the creation of 3D model templates is a straightforward solution in this regard. There is a closed catalogue of products/panels that were used during construction and products that can be implemented into predefined libraries, whereas 3D models of building types might be collected in open-source repositories. A 3D model of the given building type could then be downloaded from the repository and easily modified to match the specific technical and local conditions. We propose to create families of all systems and panels used for one type of LPS, similarly to what had been done 50 years ago. This would enable each model to be "erected" in a virtual environment using panels that it had originally been built from. If there are any commonly used LPS types, the entire buildings can be modelled as templates and then adjusted to specific locations for individual building model creation.

The process of using digital twin (DT) technology for LPS building retrofit projects proposed by the authors is shown in Figure 1 and consists of steps outlined below. The 3D models from the original project data are created per type of building and a repository of template 3D models is created; as described in the paragraph above, the most time-consuming element of work-preparation of an individual model for a specific building-is significantly simplified, reducing the 3D model creation timeframe. Secondly, all previous modernization works need to be included in such an individual model. The next step is the incorporation of the accurate representation of reality, which makes the BIM model a virtual twin of the building - this requires a link between the model and the constant input of usage data-the more data the better the twin. Therefore, the next stage involves the input of usage data (e.g., using the IES iSCAN software). In the beginning, only the available meter readings from the main meter can be imported. However, once smart meters are available, the flow of information to the software becomes constant and the model starts to recognize patterns. From that point onwards, the software algorithm can suggest energy-saving measures and the level of interference it causes (shallow/deep retrofit) or the planned retrofit works can be included in the simulations for swift estimation of costs, energy savings, public consultation use, and risk assessment before the final decision is made.

The DT process may be used for single buildings but also whole estates or districts. Considering the urban projects, the data input is simply at a different levelthe data from building smart meters are accompanied by data regarding vehicular and pedestrian traffic, the grid and utility locations, and car charging station locations. Accordingly, the DTT can be used to analyse the energy usage across the grid and point to the appropriate location for a photovoltaic panel energy-storing facility or new subterranean parking, which can first be checked virtually for any potential clashes or impact on the area's traffic.

The biggest challenge for LPS renovation-both at the building-and urban-level and second only to the substantial cost of such works-is the decision-making process with many owners and occupiers involved. The graphics and data outcome of DT technology used 


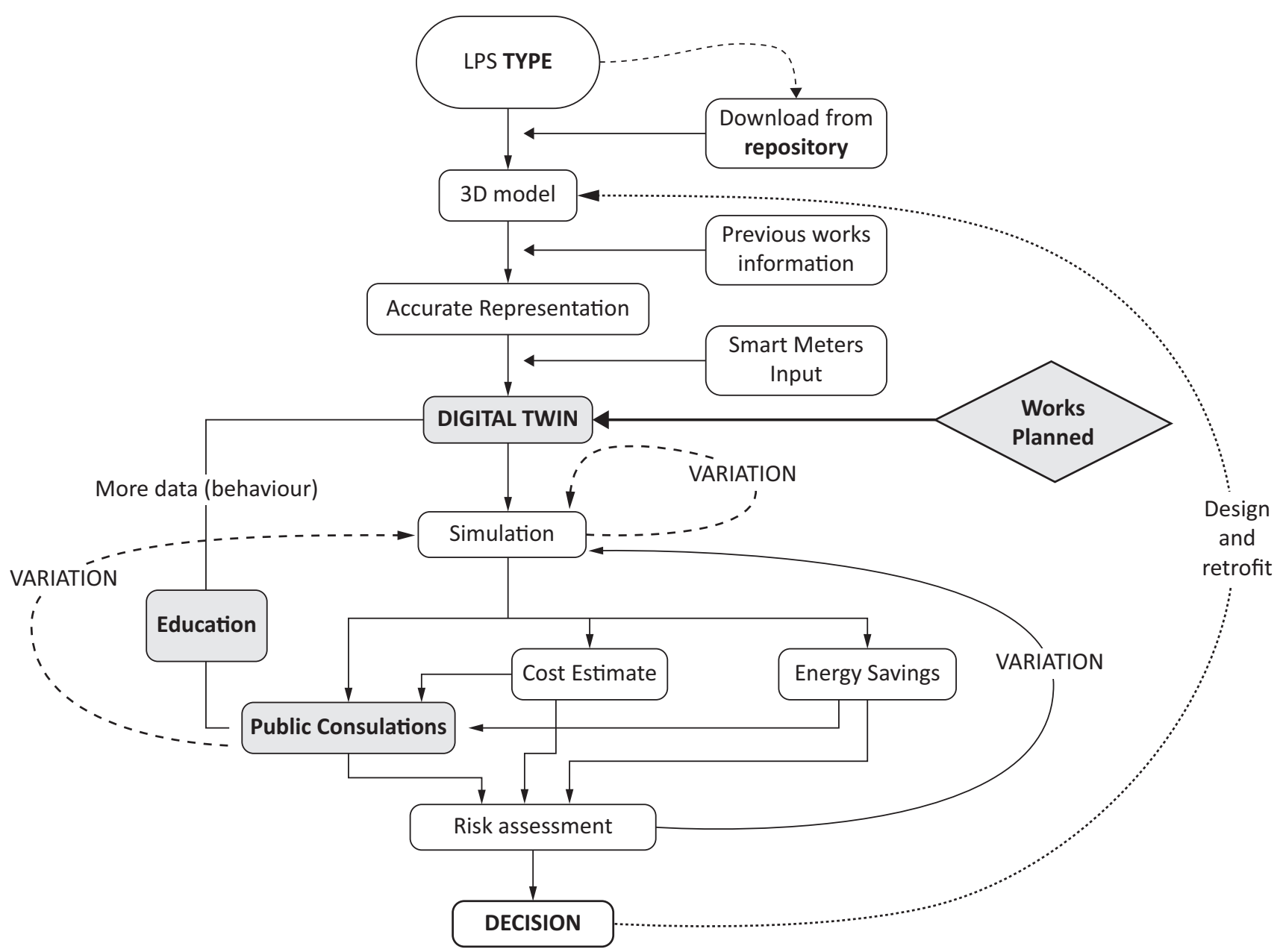

Figure 1. The DT process for LPS retrofit projects showing the directions of the information feed.

for wide consultation and information of all stakeholders allows for better decisions with lesser risks involved. Public consultation to demonstrate the advantages and disadvantages of each refurbishment option can be held as interactive workshops utilizing virtual reality simulation solutions. The added benefit of public participation is that it may help to generate trust and build up a reputation, as discussed by Baer-Pásztory and Bergmülle (2013), values which are at a lower level in CEE countries compared to Western Europe.

A big proportion of LPS buildings still require extensive modernization, as described by the Polish Building Research Institute (2019), including the upgrade of electrical and water systems, as well as ventilation systemsthe process from Figure 1 consists in the following: The housing association decides to make the necessary upgrades to the system and orders an individualized building model from the template repository to plan all works using it and check for clashes and possible conflicts with occupiers, as well as the need for consultations, the ratio of works that are intrusive for inhabitants, and the potential risks. Thanks to this, all stakeholders are prepared for all consecutive works from the start and all potential conflicts can be resolved in virtual reality, reducing the duration and cost of works. Once the indi- vidualized model is created, it forms the base for the subsequent refurbishment projects. The model with the latest changes can be imported into the DT software and populated with data from smart meters, making it a virtual twin that always remains up to date. However, the refurbishment decision is a good trigger for the model's creation; it can be commenced at any stage of a building's life in anticipation of future modernization works.

We can predict that one of the next steps in the sustainability simulation might be the reduction in water consumption and the benefits of rainwater tanks for the building's water usage. Capable of assessing the amount of water saved by analysing weather report data from the previous years, a DT can precisely estimate the water savings, effectively helping future-proof entire estates.

There are many benefits of using the virtual twin technology. For example, an apartment owner who plans refurbishment can use a DT to track all implications of the works that may affect the building systems and structure. Changes in apartments may soon be done first on a virtual building, with subsequent simulations run on a DT educated by smart metering to advise on the appropriate timing of works to avoid disruptions to other users thanks to real-time electricity, elevator, and parking zone usage patterns. As dubious as it may seem, 
similar technology is already used in the UK-constant analysis of the loads from smart meters readings provides information and makes it possible to adjust the power supply to car charging stations.

The considerable challenge for the countries of CEE is to reach the digital revolution threshold that has been crossed by Western economies in the last decade. As stated in The Rise of Digital Challengers (Novak et al., 2018, p. 6), "the digital economy of CEE countries accounts for 6.5 percent of GDP... but well behind Digital Frontrunners such as Sweden ( 9.0 percent)." In the same report (p. 12), digitalization is named "the next major growth driver" for CEE. In western economies-like the UK $-50 \%$ of households will have a smart meter installed by the end of 2021 (Holder, 2020); similarly, the EPC (Energy Performance Certificate) is a requirement for all rental agreements since 2008 (Department for Levelling Up, Housing and Communities, 2007)-it creates a vast public database from which DTs can be fed data at the building-, estate-, or district-level. By comparison, in CEE these standards are falling behind due to the slowpaced voluntary action and a limited amount of information about the potential benefits of replacing standard meters with smart ones. Considering that there are areas in Eastern Europe where children do not have broadband sufficient for remote learning/home-schooling during the Covid-2019 pandemic, the CEE requires more time to close the digital revolution gap. However, this time should be used for the creation of template models in preparation for a future data influx, and secondly, the big factual and educational campaign prepared for familiar estates can be the key to a widespread digital revolution, following the logic of behavioural replication-if old panel system buildings receive smart meters, the newer developments will follow swiftly.

End-user education is yet another critical element of DT technology that has been identified during this investigation. There are two reasons behind it. Firstly, with knowledge comes an understanding of why digital technologies (like smart metering) are beneficial and should be implemented as widely as possible. Smart meters are not merely used for the convenience of the energy company but for the actual management of the energy usage and adjustment of behaviour to become more energy efficient. But data can only be managed if it is knownthis is why constant updates on energy usage provided by a smart meter inside one's apartment, as well as a monthly bill, is a better incentive for behavioural changes than the bill alone.

The second aspect of education is even more critical than the first. This is to assure that the maximum energy saving is achieved for all thermal retrofit works-one that matches the estimates, at the very least. As described in extensive research by Galvin and Sunikka-Blank (2013), the less thermally efficient a building is, the better the user behaviour-the lack of thermal insulation is largely offset by users' everyday energy saving habits. However, the cited study revealed that once all thermal upgrades have been installed, the residents' energy-saving habits have deteriorated-the actual energy savings were $30 \%$ lower than the estimates due to detrimental changes in user behaviour. DT technology can help with reinforcing energy-saving habits as the technology enables the installation of interactive displays (large ones for a few buildings or smaller ones for each building's reception) on the estate premises to show a constant flow of energy to the given apartment and compare it to others in the building. Each inhabitant can also use a mobile app for that purpose. After the implementation of such solutions, constant feedback becomes an incentive to save more energy. Furthermore, policymakers would be limited only by their imagination in this area, e.g., they may organize wide range of contests for occupiers that might become a district tournament to constantly reinforce the residents' energy savings behaviours.

\section{Conclusion}

Thanks to the extensive use of typologies in LPS, the implementation of a 3D model-based DT technology, while initially time-consuming, is relatively uncomplicated, as 3D model templates can be widely applied. Meanwhile, the DT provides feedback on LPS retrofit at every stage, from design to operation, from cost estimations via public consultations to decisions, results, and future challenges, from energy performance and $\mathrm{CO}_{2}$ reduction goals to utility grid planning and urban improvements. The longer the DT exists and the more data it receives, the more accurate the simulations become; as such, the sooner the technology is implemented, the better for any type of LPS building retrofit project.

As the DT constantly grows with the data collected, the technology itself develops further as well. Looking ahead, the implementation of DT technology prepares the LPS estates for future challenges like noise and light pollution and any others that might occur in the rapidly urbanizing areas in the future. New requirements will simply become additional attributes applied into the digital environment with the software providing calculations of simulated outcomes.

The retrofit measures, resident education, and installation of photovoltaic panels in places with the most sun exposure (such locations to be suggested by the BIM and DT simulation) give LPS buildings the potential to become energy-positive structures, which would help enormously with the climate change and air pollution that Eastern Europe currently struggles with.

Our study provides the foundation for a new way of thinking that helps with managing the change in digitalization in CEE. Since people are often afraid of the unknown, the familiar can lead the change-the digital revolution. But once the commonplace panelák ("panel building") becomes a smart and digital building, it may be easier to convince society to follow in its footsteps. 
Additionally, it ought to help with the most important aspect of the sustainable future-the conscious useras only through responsible decisions at every level will it be possible to resolve the issue of pollution plaguing our planet.

This analysis is the first output of a wider project researching the means of giving LPS estates a new lease of life and making them sustainable even by 21st century standards while helping with the digitalization of CEE's mid-life housing stock and its inhabitants. The next step is a pilot case study including the creation of a single building model to check all potential issues with derelict material characteristics, access to data, and potential issues with the simulations. That will be followed by a planned case study modelling a whole estate to review the possibilities and challenges of using the template library. Once these challenges are identified, the plan is to test the model during public consultations-the participation project which will clearly define the most pressing areas for improvement for the inhabitants. The final step, and the authors' aim, is the creation of a repository of model types and materials that would be an open-access tool used by teams from other countries working on separate systems with the exchange of experiences from specific lessons learned.

\section{Conflict of Interests}

The authors declare no conflict of interests.

\section{References}

Absimetov, V. E., \& Solovev, D. B. (2020). The use of effective design solutions and high-tech building materials for reconstructing residential buildings of mass development in 1960-1990. In IOP Conference Series: Materials science and engineering (Vol. 753, Chapter 2, Paper No. 032027). IOP Publishing. https://doi. org/10.1088/1757-899X/753/3/032027

Anderson, J., \& Moncaster, A. (2020). Embodied carbon of concrete in buildings. Part 1: Analysis of published EPD. Buildings and Cities, 1(1), 198-217. https://doi. org/http://doi.org/10.5334/bc.59

Baer-Pásztory, J., \& Bergmülle, R. (2013). Public participation in the EU-A comparison between East and West [Paper presentation]. Impact Assessment "The Next Generation," 33rd Annual Meeting of the International Association for Impact Assessment, Alberta, Canada.

Beiser, V. (2018). The world in a grain: The story of sand and how it transformed civilization. Riverhead Books.

Bosker, M., Buringh, E., \& van Zanden, J. (2008). From Baghdad to London: Lessons from one thousand years of urbanisation in Europe and the Arab world. VOXeu. https://voxeu.org/article/1000-years-urbanhistory-rise-and-fall-european-and-arab-cities

BP. (2020). Statistical review of world energy.

Dębowski, J., Nowak, K., \& Nowak-Dzieszko, K. (2014).
Airtightness of the large panel buildings before and after thermal modernization. Technical Transactions-Architecture, 8A(15). https://www. ejournals.eu/Czasopismo-Techniczne/2014/ Architektura-Zeszyt-8-A-2014/art/4910

Dekker, K., \& Van Kempen, R. (2005). Large housing estates in Europe: A contemporary overview. Royal Dutch Geographical Society.

Department for Levelling Up, Housing and Communities. (2007). The energy performance of buildings (Certificates and inspections) (England and Wales) Regulations 2007 (S.I. 2007/991).

Eurostat. (2018). Living conditions in Europe-Housing. www.ec.europa.eu/eurostat/statistics-explained/ index.php?title=Living_conditions_in_Europe__housing

Frendler-Bielicka, J. (2013). Jak i gdzie kupujemy żywność [How and where do we shop for food]. Centrum Badania Opini Spolecznej.

Galvin, R., \& Sunikka-Blank, M. (2013). A critical appraisal of Germany's thermal retrofit policy: Turning down the heat. Springer.

Gazeta.pl. (2018). Online forum Mieszkacie w wielkiej płycie? To już niedługo... [Do you live in a large panel? It's coming soon...]. https://forum.gazeta.pl/ forum/w,567,165739662,165739662,Mieszkacie_ w_wielkiej_plycie_To_juz_niedlugo_.html

Gribat, N., \& Huxley, M. (2015). Problem spaces, problem subjects: Contesting policies in a shrinking city. In E. Gualini (Ed.), Planning and conflict (pp. 164-183). Routledge.

Holder, M. (2020, December 16). 'We're getting there': Smart meters on track to reach half of Britain's homes and businesses in 2021. Businessgreen. http://www. businessgreen.com/4025086

Hopfe, C., Soebarto, V., Crawley, D., \& Rawal, R. (2017). Understanding the differences of integrating building performance simulation in the architectural education system. In Proceedings of the 15th international conference of the international building performance (pp. 1249-1256). Simulation Association (IBPSA).

Instytut Techniki Budowlanej. (2019). Budownictwo Wielkopłytowe Raport o Stanie Technicznym [Large panel system buildings, technical condition report].

Korzeniewski, W. (1981). Poradnik Projektanta Budownictwa Mieszkaniowego [Residential housing designer's guidebook]. Arkady.

Lorenzo-Sáez, E., Oliver-Villanueva, J.-V., Coll-Aliaga, E., Lemus-Zúñiga, L.-G., Lerma-Arce, V., \& Reig-Fabado, A. (2020). Energy efficiency and GHG emissions mapping of buildings for decision-making processes against climate change at the local level. Sustainability, 12(7). https://doi.org/10.3390/su12072982

Lössl, S. (2016). Stadtumbau im Märkischen Viertel [Refurbishment at Berlin's Märkisches Viertel neighbourhood]. Metropolis. www.use.metropolis.org/ case-studies/deutschlands-grossteniedrigenergiesiedlung-das-markische-viertel 
Miesarch. (2019). Transformation of 530 dwellingsGrand Parc Bordeaux. www.miesarch.com/work/ 3889

Novak, J., Purta, M., \& Marciniak, T. (2018). The rise of digital challengers: How digitization can become the next growth engine for Central and Eastern Europe. McKinsey \& Company.

Ostańska, A. (2009). Stan techniczny i analiza energetyczna jako podstawowe aspekty rewitalizacji osiedli z budynkami wielkopłytowymi [Technical condition and energy analysis as the basic aspects of revitalization of housing estates with large-panel buildings]. Przeglad Budowlany, 9, 40-47.

Pewny Lokal. (2020). Wielka płyta czy nowe budownictwo? [Large panel or new development]. https:// pewnylokal.pl/porady/wielka-plyta-czy-nowebudownictwo

Ruggeri, A. G., Gabrielli, L., \& Scarpa, M. (2020). Energy retrofit in European building portfolios: A review of five key aspects. Sustainability, 12(18). https://doi. org/10.3390/su12187465

Speck, J. (2018). Walkable city rules: 101 steps to making better places. Island Press.

Tofiluk, A. M. (2017). Systemy prefabrykacji dla wielorodzinnego budownictwa mieszkaniowego"wielka płyta" wczoraj i dziś [Prefabrication systems for multi-family housing-"Big panel" yesterday and today]. In SBPB Stowarzyszenie Producentów Betonów (Eds.), Prefabrykacja-Jakość, trwałość, różnorodność-Beton w architekturze [Prefabrication-Quality, durability, varietyConcrete in architecture] (Vol. 5, pp. 39-49). SBPB.

Wady i zalety bloków z wielkiej płyty [Advantages and disadvantages of large panel system blocks]. (2020, July 14). Get Home. www.gethome.pl/blog/wady-izalety-blokow-z-wielkiej-plyty

\section{About the Authors}

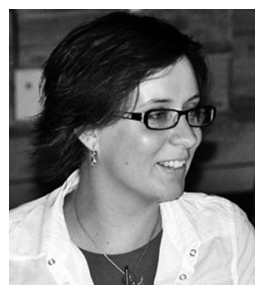

Paulina Duch-Zebrowska is a researcher at the Faculty of Architecture, Gdańsk University of Technology. She applies extensive experience gained in her previous career in commercial architecture in her research projects aimed at bringing existing buildings to the current sustainability standard, as well as her scientific interest is in passive design and energy-positive buildings.

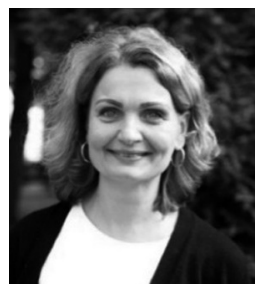

Katarzyna Zielonko-Jung is an assistant professor at the Faculty of Architecture, Gdańsk University of Technology. Her scientific interests focus primarily on issues connected to ecological architecture and urban solutions, and on the correlation between the shape of building development and microclimatic phenomena that occur within urban spaces, especially in terms of aerodynamic phenomena. She is the author and co-author of numerous publications, including the following monographs: Combining Advanced and Traditional Technologies Within Ecological Architecture (2012), Contemporary Ecological Architecture (2012), and Shaping of Ecological Architecture in Urban Structure (2013). 